\title{
大都市圈郊外に括忷る買い物行動の縦断データ分析 一平城ニュータウン居住者を事例に一
}

\section{稲 垣稯 *}

(2018年12月 6 日受付， 2019 年 3 月 16 日受理)

\section{I はじめに}

II 対象地域の概要と調査方法

1 平城ニュータウンの概要

2 アンケート調査の方法

III 利用店舗の業態構成

$\begin{array}{ll}1 & \text { 高級服 } \\ 2 & \text { 普段着 }\end{array}$
IV 買い物先の空間的特性

1 高級服

2 普段着

$\mathrm{V}$ 主要買い物先における利用店舗の業態 構成

1 高級服

2 普段着

VI㐨りに

\begin{abstract}
摘要
横断データにもとづいて大都市圏郊外の買い物行動を明らかにした研究は数多く存在するが, 縦断 データに焦点を当てた研究は少ない。本研究では, 大阪大都市圈の郊外に居住する人々の買い物行動 に関する長期的な縦断データを収集する。対象地域は大阪大都市圏の東部郊外に位置する奈良市の平 城ニュータウンであり，アンケート調査にもとついて分析を行った。バブル経済期までは，大阪大都 市圈の上位中心地である難波・心斎橋, 下位中心地である大和西大寺駅周辺で高級服を購入するスタ イルが維持されていたが，バブル経済崩壊以降難波・心斎橋の利用割合が大幅に低下した。最寄品で ある普段着の購入に捻いても，1980年時点では百貨店の利用が一定程度あった。しかし1980年代以降， 平城ニュータウンに総合スーパーが立地したことにより, 普段着を平城ニュータウン内で購入する割 合が上昇した。本研究では, 大都市圏に拈ける買、物環境の変化に伴い郊外居住者の買い物行動が絶 えず変化してきたこと, さらには現住地への入居時期により買い物行動の変化の仕方が異なることを 明らかにした。
\end{abstract}

キーワード : 大都市圏郊外, 買、物行動, 縦断データ, 高級服, 普段着, 平城ニュータウン

\footnotetext{
*奈良大学文学部Ｅ-mail: inagakir@daibutsu.nara-u.ac.jp
} 


\section{Longitudinal Data Analysis on Shopping Behaviors in Metropolitan Suburbs: A Case Study of the Residents of Heijo New Town, Nara City INAGAKI Ryo}

Faculty of Letters, Nara University

(Received on 6 December, 2018; Accepted on 16 March, 2019)

Many studies have examined shopping behaviors in metropolitan suburbs through cross-sectional surveys. However, few studies have focused on longitudinal data. The present investigation collected long-term longitudinal data on the shopping behaviors of people residing in the suburbs of the Osaka metropolitan area. The study area comprised Heijo New Town in Nara city, an eastern suburb of the Osaka metropolitan area. Data were obtained from a questionnaire survey. The results of the examination revealed that customers of luxury clothing maintained largely the same purchasing behavior up to the bubble economy period, purchasing from either Namba-Shinsaibashi (the higher-ranked central location in the Osaka metropolitan area) or from the vicinity of the Yamato-Saidaiji Station (the lower-ranked central neighborhood). After the collapse of economic bubble, the shopping share of the Namba-Shinsaibashi area decreased considerably. In 1980, customers still purchased convenience goods, such as everyday clothes, from department stores. However, after the 1980s, a general merchandise store was built in Heijo New Town, where the purchasing of everyday clothes increased. This paper demonstrates that the shopping behavior of suburban residents changed as the shopping environment in the metropolitan area transformed. Further, the manner in which customers altered their purchase behaviors differed, depending on the time they started living at their current residence.

Key words: metropolitan suburbs, shopping behavior, longitudinal data, luxury clothing, everyday clothing, Heijo New Town

\section{I はじめに}

雇用や消費において強い吸引力を有する大都市 と，そこへ日常的に移動する人々の居住機能に特 化した郊外からなる大都市圏は, 戦後の高度経済 成長期に成立した。その後, 郊外に和ける雇用や 小売・サービス業の立地により, 当初の大都市 圏構造は大きく変容してきた（富田, 1995; 藤井, 1990）。これら諸機能の郊外立地により, 大都市 と郊外の間の結合関係は大きく変化してきたが, この結合関係の変化を具体的に示す指標として取 り上げられてきたのが，通勤行動と買い物行動で ある（藤井, 1990）。

これまでに筆者は, 通勤行動を指標として, 大
都市と郊外の結合関係の変化に着目してきた（稲 垣, 2011, 2014, 2016)。そこでは，さまざまな側 面に拀いて，郊外居住者が大都市との通勤による 結合関係を弱めてきたことが明らかになった。一 方，通勤以上に大きな変化があったと考觉られる のが買い物行動である。居住地付近にオフィスや 工場などが立地したとしても，すでに勤め先を もっている人の通勤先の変化につながることは少 ないのに対し, 小売施設の立地は, 即座に買い物 行動の変化に結びつきうるからである。

買い物行動に対してはさまざまな学問分野から 関心が寄せられてきたが, 地理学が着目してきた のはその空間的行動にある（生田, 1991）。とり わけ大都市圏構造の変容に関する議論の中では, 
大都市に依存してきた郊外居住者の買い物行動が， 郊外への小売業の立地によりいかに変化してきた のかが注目されてきた（富田, 1995; 藤井, 1990）。

郊外地域を対象とするこれまでの買い物行動の 研究を振り返ると ${ }^{1)}$, 大都市圈の空間構造を把握す ることを目的としてパーソントリップ調査を用いた 石川 (2008), 駒木 (2004), 吉田・加藤 (2015), 自治体をはじめとする公的機関が実施した買い 物調査を分析した伊東 (1978), 根田 (2006), 林 (1979), 藤井 (1989), 正木 (1999), 独自のアン ケート調査を分析した荒井（1979）, 岩動（2005）, 市南・星 (1983), 小金澤・小野 (2016), 崔・鈴 木 (2012), 戸所 (1981), 橋 (1989), 吉川 (2007) など数多く存在する。しかし，これらの研究はい ずれも, 調査時点の買い物行動を取り上げたにと どまる。こうした 1 時点のみのデータ ${ }^{2)}$ では，そ の買い物行動が何らかの買い物環境や地域構造の 変化によるものなのか否かを判断することができ ない。そのため, 複数時点に拈ける買い物行動の 変化を検討することが重要となる。

生田（2008），川口（1992）, 藤井 $(1983,1986 ）$ は, 大都市圈や都道府県といった広域スケールに拀い て, 自治体が実施した複数時点の買い物行動調査 をもとに，郊外内部を指向する割合の变化を考察 している。また，駒木（2010），駒木ほか（2008） は, 特定の都市地域を対象とし, 当該地域におけ る買い物環境の変化と買い物行動とを結びつけた 分析を行っている。千葉 $(2009,2013)$ は, ょり 具体的に, 特定の大型店の進出前後に拈ける買い 物行動の変化を, 地元の財団法人によって実施さ れたアンケート調査をもとに考察している。さら に古賀ほか（2004）は，2時点に氺いてアンケー 卜調査を実施し，その間の買い物行動の变化を考 察している。

しかし, 上記の研究は, 各時点に和いて実施さ
れた横断データどらしを比較しており, 各時点に おける回答者は同一ではない。すなわち，個人の 買い物行動が 2 時点の間でどのように变化したの かを明らかにしたものではない。このことは，郊 外居住者の買い物行動の変化を見䛊る可能性をは らんでいる。例えば， 2 時点のうち，期首から当 該地域に居住していた人々の買い物行動が期末に 拈いても変化がなかったとしても，その間に入居 してきた人々の買い物行動が当初からの居住者と 異なっていれば，当該地域の居住者の買い物行動 は「変化」したことになる。

このように, 回答者の異なる別々の横断データ を利用することによって生じる問題点を解決する ためには，買い物行動に関する縦断データを収集 する必要がある。縦断データであれば， ある時点 間の買い物行動の変化を個人レベルで追跡するこ とが可能になる。縦断データを用いた研究はわず かではあるが存在する（荒井, 1981; 生田・篠崎, 1987; 小堀・杉浦, 1995; 富田, 1978; 堀, 2014)。乙 かし, これらの研究が取り上げている過去の買い 物行動とは 5 年前や 10 年前のものであり, 短期間 に拈ける買い物行動の変化を検討するにとどまっ ている。大都市圈構造の変容にかかわる小売業の 動向を振り返ると, 小売業全般の郊外立地（富田, 1995), 大店法の規制緩和や大店立地法の施行に ともなら総合スーパーチェーンの多店舗展開（伊 藤, 2007; 安倉, 2004), そして近年に打ける百貨 店の衰退（伊藤, 2007; 岩間, 2004）など, 長期に わたってさまざまな変化を経験してきた。こうし た状況をふまえれば，短期的な買い物行動の变化 だけでなく，大都市圈の時代的文脈に即した長期 的な変化を追跡することが肝要であろう。

大都市圈構造の変容に関して長期的な縦断デー タを利用した研究は, すでに通勤流動の分野に 拈いてなされてきた（稲垣, 2001; 谷, 1998)。谷

1)ここでは，大都市圈郊外だけでなく，地方中心都市などの郊外を対象とした主な研究も取り上げる。

2)このよらな, 1 時点のみで得られたデータは横断データと呼ばれる。 
（1998）は，通勤先に関する縦断データを用いるこ とによってそそれまでの横断データによる分析で は推測に頼らざるを得なかった大都市圏の通勤流 動パターンの変化を明瞭な形で説明した。本研究 では，こらしたアプローチを買い物行動に援用す ることにより, 大都市圏に拈ける買い物行動の変化 に対する新たな知見を提示することを目的とする。

\section{II 対象地域の概要と調査方法}

\section{1 平城二ュータウンの概要}

本研究で対象とするのは，大阪大都市圈の郊外 に位置する奈良市の平城ニュータウンである（第 1 図)。平城ニュータウンは, 奈良市北部の平城
山丘陵に扔いて, 日本住宅公団によって開発さ れた大規模住宅団地である。北側で接する相楽 ニュータウン（京都府木津川市, 精華町）とは一 体的な開発がなされており，両者はあわせて「平 城・相楽ニュータウン」と総称される。入居開 始は, 平城ニュータウンが 1972 年, 相楽ニュー

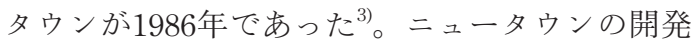
にあわせ，1972年に近鉄京都線・高の原駅が開 設された。高の原駅を中心とする地区は，平城・ 相楽ニュータウンの地区センターに位置づけられ て扣り，各種の小売施設，行政施設，医療施設が 集中している。

第 2 図は, 平城ニュータウンに专ける人口と世 帯数の推移を示したものである。人口，世帯数と

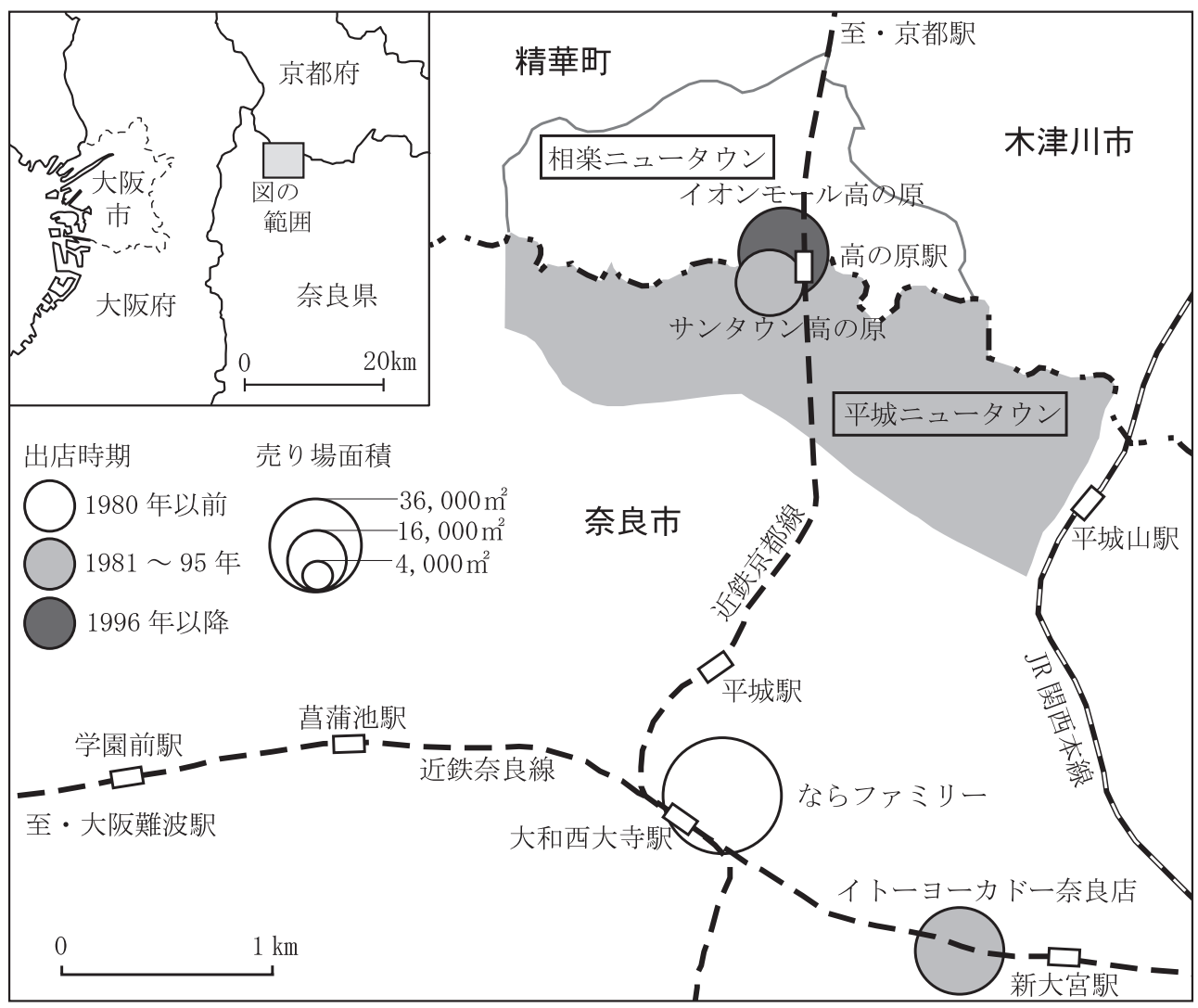

第 1 図 研究対象地域と周辺の大型店

Figure 1. Study area and locations of large-scale retail stores

ならファミリーは，近鉄百貨店奈良店とイオン奈良店からなる。

資料：『全国大型小売店総覧2017』による。 
世帯

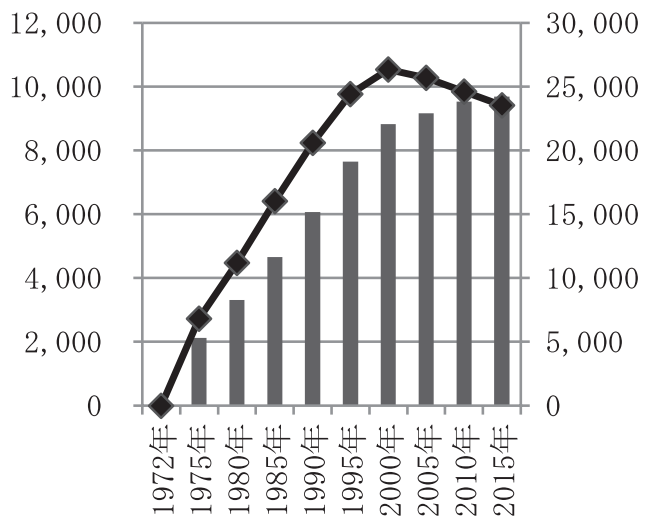

世帯数

第 2 図 平城ニュータウンの人口と世帯数の推移

Figure 2. Changes of the number of population and households in Heijo New Town

資料：「奈良市統計書」,「統計なら」による。

もに1970年代から1990年代までは継続的に増加 を示してきたが，2000年以降になると人口は減 少傾向にある。これは，子ども世代の離家や初期 入居者の死亡・転出による部分が大きいと考光ら れる。一方，世帯数は，緩やかながら2000年以 降も増加を継続して扔り, 新規入居者が一定数存 在することを示唆する。このように, 平城ニュー タウンでは, 1970年代から現在に至るまで, 程 度の差こそあれ絶えず新規入居者が流入してきて 抢り，さまざまな世代が混在する状況にある。

\section{2 アンケート調査の方法}

本研究では, アンケート調査により, 郊外居住 者の買い物行動に関する縦断データを収集する。
従来の研究では, 主に世帯の代表者一人の買い物 行動を取り上げる事例が中心であり，その対象の 多くは女性（配偶者）であった。これは，「男性 $=$ 就業, 女性 $=$ 買い物 (家事)」といら図式を想 定したものと考光られるが，このよらな図式は不 正確であり，男性も買い物を行ら主体である。そ こで本研究では, 男性の買い物行動にも着目する。

前節で示したように, 平城ニュータウン居住 者の入居時期は一様でなく，入居が開始された 1970年代からの居住世帯もあれば，最近になっ て入居してきた世帯も存在する（第 2 図）。そこ で本研究では, 入居時期の違いも考慮に入れるこ ととする。具体的には，1980年以前，1981～95年， 1996年以降それぞれの時期に入居したグループ ごとに分析を行ら。入居時期によってサンプルを 区分することには，I 章でも言及したように，当 初からの入居者とその後の入居者との間の差違を 検討できるという意義がある。

調査する買い物行動の時点については，1980年， 1995年，そして調査時である2016年の 3 時点とし た。1980年以前入居者は1980年，1995年，2016年 の 3 時点, 1981 95年入居者は1995年, 2016年の 2 時点, 1996 年以降入居者は 2016 年の 1 時点に おける買い物行動について回答してもらっだ)。

また本研究では, 縦断的な分析や, 居住者の入 居時期による買い物行動の差異に着目することを 重視する観点から，数多くの品目を取り上げるよ りも, 品目を絞って調査を行った。すなわち, 買 回品, 最寄品の事例としてそれぞれ高級服, 普段 着を取り上げ5)，それぞれについて最もよく購入

3) 相楽ニュータゥンの開発が遅れた要因として, 近鉄奈良線沿線などにおいてすでに都市的開発のすすんでいた奈 良市とは対照的に, 当時の京都府側（南山城地域）には都市化の波は及んで拈らず，開発に対する意識が十分に 浸透していなかったことや，広域計画や都市計画を策定するための時間が必要であったことなどが挙げられる (杉本, 1995; 山田・大木, 1979)。

4) すなわち, 買い物行動の時間的変化を考察できるのは, 1980年以前入居者については 3 時点, 1981 95年入居 者については 2 時点であり，1996年以降入居者は調查時点（2016年）の情報が得られるのみで，時間的変化を 考察することはできない。

5) アンケート調査では, 回収率を高めることを優先するため, 高級服, 普段着の細かな定義については回答者に例 示していない。すなわち，何を高級服，普段着とみなすかは回答者の判断にまかせている。 
する店舗の業態，買い物先の地域などを分析する ${ }^{6)}$

アンケート調査は，日本郵便による指定地区内 全戸配達サービスであるタウンプラスを利用し， 平城ニュータウンの全世帯 $(9,541$ 世帯) に対し て2016年 8 月に郵送した。 1 世帯につき 2 通の 調査票を同封し，世帯主と配偶者それぞれに回答 を求めた。記入された調查票は，料金受取人払に よって返送してもらった。この結果, 配付世帯 の $23.1 \%$ に相当する 2,204 世帯から返信があった。 なお，回答者の中には賃貸住宅や分譲マンション の居住者も存在するが，本研究では，現住所への 定着者であると考兄られる一戸建て住宅居住者の みに対象を限定する。このため，最終的な分析対
象は， 1,155 世帯の 2,107 人である。入居時期ごと の年齢構成は第 1 表に示すと扣りであり，居住期 間の長い1980年以前入居者の高齢者割合は高く, 居住期間の短い1996年以降入居者では40歳代以 下や50歳代が多い。

\section{III 利用店舗の業態構成}

\section{1 高級服}

本章では，買い物先である店舗の業態)がどの ように変化してきたのかに着目する。まず高級服 から検討する (第 2 表)。性別による差異をみると， いずれの時点でも女性の百貨店指向が強い。男性

第 1 表 入居時期別にみた回答者の年龄構成

Table 1. Age composition of survey respondents by move-in time

\begin{tabular}{|c|c|c|c|c|}
\hline & 40歳代以下 & 50歳代 & 60歳代 & 70歳代以上 \\
\hline 1980年以前入居 & $(2.8)$ & $(3.4)$ & $72(20.5)$ & 258 (73.3) \\
\hline 1981～95年入居 & $(2.2)$ & $114(13.0)$ & $371(42.4)$ & $371(42.4)$ \\
\hline 1996年以降入居 & $261(33.6)$ & 207（26.7） & $215(27.7)$ & $93(12.0)$ \\
\hline
\end{tabular}

カッコ内は構成比 $(\%)$ 。

資料：平城ニュータウンアンケート調査による。

第 2 表 高級服の購入店舗の業態

Table 2. Retail format to purchase luxury clothing

\begin{tabular}{|c|c|c|c|c|c|c|c|}
\hline & \multirow{2}{*}{$\begin{array}{c}\text { 1980年 } \\
\text { 1980年以前 } \\
\text { 入居 }\end{array}$} & \multicolumn{2}{|c|}{ 1995年 } & \multicolumn{3}{|c|}{ 2016年 } \\
\hline & & & $\begin{array}{c}\text { 1980年以前 } \\
\text { 入居 }\end{array}$ & $\begin{array}{c}\text { 1981 95年 } \\
\text { 入居 }\end{array}$ & $\begin{array}{c}\text { 1980年以前 } \\
\text { 入居 }\end{array}$ & $\begin{array}{c}\text { 1981 95年 } \\
\text { 入居 }\end{array}$ & $\begin{array}{c}\text { 1996年以降 } \\
\text { 入居 }\end{array}$ \\
\hline \multirow{4}{*}{$\begin{array}{l}\text { 男 } \\
\text { 性 }\end{array}$} & 百貨店 & $105(80.2)$ & $113(79.0)$ & 268（75.5） & $96 \quad(69.6)$ & 217 (63.3) & $206 \quad(61.9)$ \\
\hline & 総合スーパー & $11 \quad(8.4)$ & $11 \quad(7.7)$ & $19 \quad(5.4)$ & 19 (13.8) & $53(15.5)$ & $43(12.9)$ \\
\hline & 衣料品専門店 & $11 \quad(8.4)$ & (8.4) & $44 \quad(12.4)$ & $17(12.3)$ & $48 \quad(14.0)$ & $53(15.9)$ \\
\hline & その他 & $4 \quad(3.1)$ & $(4.9)$ & $24 \quad(6.8)$ & $6 \quad(4.3)$ & $25 \quad(7.3)$ & $31 \quad(9.3)$ \\
\hline \multirow{4}{*}{$\begin{array}{l}\text { 女 } \\
\text { 性 }\end{array}$} & 百貨店 & 149 (89.8) & $160(91.4)$ & 377 (89.5) & $141(80.6)$ & $343(80.5)$ & $292(77.9)$ \\
\hline & 総合スーパー & $7 \quad(4.2)$ & $3 \quad(1.7)$ & $12 \quad(2.9)$ & $19(10.9)$ & $37 \quad(8.7)$ & 47 (12.5) \\
\hline & 衣料品専門店 & $4 \quad(2.4)$ & (2.9) & (2.9) & $7 \quad(4.0)$ & (5.4) & $15 \quad(4.0)$ \\
\hline & その他 & $6 \quad(3.6)$ & $(4.0)$ & $(4.8)$ & $(4.6)$ & $(5.4)$ & (5.6) \\
\hline
\end{tabular}

カッコ内は構成比 $(\%)$ 。

資料：平城ニュータウンアンケート調査による。

6) アンケート調査では, 高級服, 普段着のほかに生鮮食料品についても尋ねたが，活かの 2 品目に比べて各時点間 や入居時期による差異が小さく，縦断分析の対象として取り上げる必要性が小さいと考えられる。そのため，生 鮮食料品についてはここでは取り上げない。

7) アンケート調査では, 衣料品専門店であっても, 総合スーパーを核店舗とするショッピングモール内に入居して いる店舗を利用する場合は総合スーパーとして記入してもらった。 
において衣料品専門店の利用割合が高いのは，紳 士服専門店の存在によるものと考觉られる。

1980年以前入居者について，1980年から1995年 にかけての利用店舗の業態構成には大きな変化は なく，男性の約 $80 \%$ ，女性の約 $90 \%$ が百貨店を 利用する状況である。1995年はバブル経済崩壊後 に相当するが，少なくとも高級服の買い物に対し てはバブル経済崩壊の影響がまだそれ汪ど及んで いなかった。1981〜95年入居者をみると，1995 年時点に扣ける利用店舗の業態構成は，1980年 以前入居者のそれと大きな差異はない。すなわち， 1995年時点では，いずれの時期の入居者におい ても高級服を購入するのに百貨店を利用するとい ら買い物行動が定着していたといえよう。

このよらな状況は，1995年から2016年にかけて 大きく変化する。1980年以前入居者，1981～95年 入居者の男女いずれをみても, 百貨店の利用割合 が約10ポイント低下している。対照的に利用割合 が上昇したのは総合スーパーである。この時期は, 1990 年代の大店法規制緩和や 2000 年の大店法廃 止にともない，一般に大型総合スーパーの立地が すすんだ時期でもある（伊藤, 2007; 安倉, 2004）。 このよらに, 一部ではあるものの, 高級服の買い 物先が百貨店から総合スーパーヘとシフトして いる。
2016年時点について，1996年以降入居者の百貨 店利用割合をみると，1980年以前入居者，1981 ～95年入居者に比べやや低く, 最も新しく平城 ニュータウンに入居してきた人々は，入居当初か ら百貨店指向が弱い。このことから，近年に拈け る百貨店の衰退は, 百貨店指向の強かった人々 （1980年以前入居者，1981 95年入居者）の百貨 店離れだけでなく，バブル経済崩壊後に住宅を取 得した人々（1996年以降入居者）を新たに取り 込むことができなかったことも関係していると考 えることができる。

\section{2 普段着}

第 3 表は，普段着における利用店舗の業態構成 を示したものである。高級服（第 2 表）と比較す ると, 総合スーパーや衣料品専門店の割合が高 いのが特徵である。ただし，1980年には，1980 年以前入居者の 4 分の 1 以上（男性 $26.7 \%$, 女性 30.7\%）が百貨店を利用して拈り，高級服汪どで はないものの，普段着に捻いても百貨店を指向す る傾向にあったことがわかる。

1995年になると，1980年以前入居者の百貨店 利用割合が大幅に低下し，その分総合スーパーが 上昇している。高級服では，1980年から1995年 にかけて店舗の業態構成に大きな变化はなかった

第 3 表 普段着の購入店舗の業態

Table 3. Retail format to purchase everyday clothing

\begin{tabular}{|c|c|c|c|c|c|c|c|}
\hline & \multirow{2}{*}{$\begin{array}{c}\text { 1980年 } \\
\text { 1980年以前 } \\
\text { 入居 }\end{array}$} & \multicolumn{2}{|c|}{ 1995年 } & \multicolumn{3}{|c|}{ 2016年 } \\
\hline & & & $\begin{array}{c}\text { 1980年以前 } \\
\text { 入居 }\end{array}$ & $\begin{array}{c}\text { 1981 95年 } \\
\text { 入居 }\end{array}$ & $\begin{array}{c}\text { 1980年以前 } \\
\text { 入居 }\end{array}$ & $\begin{array}{c}\text { 1981 95年 } \\
\text { 入居 }\end{array}$ & $\begin{array}{c}1996 \text { 年以降 } \\
\text { 入居 }\end{array}$ \\
\hline \multirow{4}{*}{$\begin{array}{l}\text { 男 } \\
\text { 性 }\end{array}$} & 百貨店 & $36 \quad(26.7)$ & $29(19.6)$ & 63 (16.8) & $12 \quad(7.7)$ & $(5.2)$ & $22 \quad(6.2)$ \\
\hline & 総合スーパー & $55(40.7)$ & 72 (48.6) & 195（52.1） & 108（69.7） & 248（64.6） & $252(71.0)$ \\
\hline & 衣料品専門店 & $28 \quad(20.7)$ & $30 \quad(20.3)$ & $78 \quad(20.9)$ & $31 \quad(20.0)$ & $88 \quad(22.9)$ & 58 (16.3) \\
\hline & その他 & $16(11.9)$ & 17 (11.5) & $38(10.2)$ & $4 \quad(2.6)$ & $28 \quad(7.3)$ & $23 \quad(6.5)$ \\
\hline \multirow{4}{*}{$\begin{array}{l}\text { 女 } \\
\text { 性 }\end{array}$} & 百貨店 & $51 \quad(30.7)$ & 35 (19.8) & $99(22.8)$ & $20(10.9)$ & $50(11.2)$ & $29 \quad(7.4)$ \\
\hline & 総合スーパー & 62 (37.3) & $90 \quad(50.8)$ & $207(47.7)$ & $110 \quad(59.8)$ & 273（61.1） & 271 (68.8) \\
\hline & 衣料品専門店 & $26 \quad(15.7)$ & $29(16.4)$ & 64（14.7） & $34(18.5)$ & $80 \quad(17.9)$ & $67(17.0)$ \\
\hline & その他 & $27(16.3)$ & $23(13.0)$ & 64 (14.7) & $20 \quad(10.9)$ & $44 \quad(9.8)$ & $27 \quad(6.9)$ \\
\hline
\end{tabular}

カッコ内は構成比 $(\%)$ 。

資料：平城ニュータウンアンケート調査による。 
が (第 2 表)，普段着では早くもこの時期に百貨 店離れが生じている。すなわちバブル経済崩壊以 降の百貨店離れは，すべての商品で一律にすすん だわけではなく，まずは最寄品の買い物先を総合 スーパーなどに変更することです寸んだものと解 勫できる8)。

2016年になると，1980年以前入居者，1981～95 年入居者のいずれにおいても百貨店の割合はさ らに低下し，男性は7.7\%，5.2\%，女性は $10.9 \%$ ， $11.2 \%$ となっている。1996年以降入居者も同様で あり，普段着を百貨店で購入するといらスタイル は，現在に拈いては注涪失われている。百貨店に 代わって大幅な上昇を示しているのが総合スー パーであり，どの入居時期，性別をみても $6 \sim 7$ 割にのぼる。カテゴリーキラーの成長により総合 スーパーが不振に陥っていることが指摘されるが (月泉, 2007)，ここでみるかぎりは総合スーパーに 一定の優位性がみられる9

\section{IV 買い物先の空間的特性}

\section{1 高級服}

本章では，買い物行動の空間的側面に着目し， 買い物を行ら場所がどのように変化していったの かを検討する。第 4 表は，高級服を購入する場所 について示したものである。1980年以前入居者の
1980年に打ける買い物場所をみると, 大和西大寺 駅周辺, 次いで難波・心斎橋の割合が高くなって いる。難波・心斎橋は, 百貨店をはじめ小売施設 が集中する大阪大都市圏の上位中心地であり, 高 の原駅から大阪難波駅までは，近鉄京都線，奈良 線を利用して約45分で到着できる ${ }^{10)}$ 。一方，大和 西大寺駅周辺は奈良市内の商業中心の一つであり， 大阪大都市圈といらスケールでは下位中心地に位 置づけることができる。大和西大寺駅前に立地す る近鉄百貨店が開業したのは1972年であるが，こ の時期は，当該地域のみならず，高度経済成長や 人口の郊外化を背景に, 百貨店の郊外立地がす寸 んだ時期でもある。なお，難波・心斎橋とならぶ 大阪市の都心である大阪駅周辺の割合が高くない のは, 平城ニュータウンからはやや遠く, 大阪駅 までの間に難波・心斎橋が存在するためである。

1980年以前入居者の1980年と1995年の買い物 場所には，大和西大寺駅周辺と難波・心斎橋の 2 つを指向するといら点で大きな変化はない。1981 ～95年入居者についてもほぼ同様の傾向であり， 高級服をこれら上位，下位中心地で購入するとい ら買い物パターンが1995年時点まで継続してい たと考光られる ${ }^{11)}$

1995年から2016年にかけての時期をみると， 1980年以前入居者，1981～95年入居者のいずれも， 難波・心斎橋の割合が大幅に低下している。一方，

8）商業動態統計によれば，大阪大都市圈（データの制約上，ここでは経済産業省近畿経済産業局管内）における百 貨店（衣料品）の販売額は，1991年の 1 兆2,703億円をピークにその後減少していくが，1990年代で下げ止まる ことはなく，2000年代以降もさらに減少がす寸んだ。この赹勢は，本調査に抢ける高級服と普段着の百貨店利 用割合の推移とある程度対応しているとみることができる。すなわち, 普段着の百貨店利用割合のみが低下した 1990年代に対し，2000年代以降は普段着の及ならず高級服にも百貨店利用割合の低下が及んだため，百貨店の 販売額が1990年代よりもさらに減少していったと解釈できる。ただしこの解釈は, 百貨店利用者のうち郊外居 住者の側のみからみたものである。

9) 先述の通り, 総合スーパーを核店舗とするショッピングモール内に入居している衣料品専門店の場合は総合スー パーとして記入してもらっているため，衣料品専門店の利用が過小評価されている可能性もある。

10) 平城ニュータウンの東側には JR 関西本線・平城山駅が存在するが (第 1 図), JR 関西本線の運行本数は近鉄線 に比べて格段に少なく, 平城ニュータウンを走行するバス路線の大半は高の原駅と接続し, 平城山駅とはほとん ぞ接続していない。このため, JR 関西本線を利用して大阪市内へ向から平城ニュータウン居住者は少ないと考 えられる。このことは, JR 関西本線天王寺駅周辺で買い物をする割合（第 4 表では「大阪市その他」に含ま れる）が小さいことからも推察できる。 
第 4 表 高級服の買い物場所

Table 4. Purchasing place of luxury clothing

\begin{tabular}{|c|c|c|c|c|c|c|c|}
\hline & \multirow{2}{*}{$\begin{array}{c}\text { 1980年 } \\
\text { 1980年以前 } \\
\text { 入居 }\end{array}$} & \multicolumn{2}{|c|}{ 1995年 } & \multicolumn{3}{|c|}{ 2016年 } \\
\hline & & & $\begin{array}{c}\text { 1980年以前 } \\
\text { 入居 }\end{array}$ & $\begin{array}{c}\text { 1981 95年 } \\
\text { 入居 }\end{array}$ & $\begin{array}{c}\text { 1980年以前 } \\
\text { 入居 }\end{array}$ & $\begin{array}{c}\text { 1981 95年 } \\
\text { 入居 }\end{array}$ & $\begin{array}{c}\text { 1996年以降 } \\
\text { 入居 }\end{array}$ \\
\hline \multirow{8}{*}{$\begin{array}{l}\text { 男 } \\
\text { 性 }\end{array}$} & 平城・相楽 NT & $7 \quad(5.4)$ & $15(10.7)$ & $27 \quad(7.5)$ & $24(17.5)$ & $60(17.4)$ & $43(12.8)$ \\
\hline & 大和西大寺駅周辺 & $58(44.6)$ & $62(44.3)$ & $156(43.5)$ & $63(46.0)$ & $148(43.0)$ & $135(40.3)$ \\
\hline & 平城・相楽 NT 周辺市町村 & $14(10.8)$ & $9 \quad(6.4)$ & $42(11.7)$ & $10 \quad(7.3)$ & $37(10.8)$ & $28 \quad(8.4)$ \\
\hline & 京都市都心 ～～～～～～～～～～～～～都 & $2 \quad(1.5)$ & $2 \quad(1.4)$ & $17 \quad(4.7)$ & $5 \quad(3.6)$ & $13 \quad(3.8)$ & $31 \quad(9.3)$ \\
\hline & 難波・心斎橋 & $34(26.2)$ & $32(22.9)$ & $64(17.8)$ & $21 \quad(15.3)$ & $42(12.2)$ & $51(15.2)$ \\
\hline & 大阪駅周辺 & $7 \quad(5.4)$ & $8 \quad(5.7)$ & $19 \quad(5.3)$ & $9 \quad(6.6)$ & $15 \quad(4.4)$ & $17 \quad(5.1)$ \\
\hline & 大阪市その他 & $5 \quad(3.8)$ & $(6.4)$ & $22 \quad(6.1)$ & $(3.6)$ & $(4.1)$ & $(2.7)$ \\
\hline & その他 & $3 \quad(2.3)$ & $3 \quad(2.1)$ & $12 \quad(3.3)$ & $0 \quad(0.0)$ & $(4.4)$ & (6.3) \\
\hline \multirow{8}{*}{$\begin{array}{l}\text { 女 } \\
\text { 性 }\end{array}$} & 平城・相楽 NT & $9 \quad(5.4)$ & $9 \quad(5.3)$ & $15 \quad(3.6)$ & $22(12.8)$ & $41 \quad(9.8)$ & $37 \quad(9.8)$ \\
\hline & 大和西大寺駅周辺 & $76(45.8)$ & $79(46.2)$ & $209(49.6)$ & $82(47.7)$ & $195(46.5)$ & $149(39.6)$ \\
\hline & 平城・相楽 NT 周辺市町村 & $7 \quad(4.2)$ & $13 \quad(7.6)$ & $40 \quad(9.5)$ & $5 \quad(2.9)$ & $21 \quad(5.0)$ & $17 \quad(4.5)$ \\
\hline & 京都市都心 ～～～～～～～～～ & $14 \quad(8.4)$ & $13 \quad(7.6)$ & $35 \quad(8.3)$ & $14 \quad(8.1)$ & $46(11.0)$ & $53(14.1)$ \\
\hline & 難波・心斎橋 & $42(25.3)$ & $41 \quad(24.0)$ & $82(19.5)$ & $29(16.9)$ & $69(16.5)$ & $54(14.4)$ \\
\hline & 大阪駅周辺 & $9 \quad(5.4)$ & $11 \quad(6.4)$ & $14 \quad(3.3)$ & $10 \quad(5.8)$ & $21 \quad(5.0)$ & $28 \quad(7.4)$ \\
\hline & 大阪市その他 & $5 \quad(3.0)$ & $(1.2)$ & $(4.3)$ & $(2.9)$ & $(4.1)$ & (5.1) \\
\hline & その他 & $4 \quad(2.4)$ & (1.8) & $(1.9)$ & $(2.9)$ & $(2.1)$ & $(5.1)$ \\
\hline
\end{tabular}

平城・相楽 NT 周辺市町村とは，奈良市・木津川市・精華町のらち平城・相楽 NT，大和西大寺駅周辺を除いたも のであり，大阪市その他とは，大阪市のうち難波・心斎橋，大阪駅周辺を除いたもの（以下，同様）。

カッコ内は構成比 $(\%)$ 。

資料：平城ニュータウンアンケート調査による。

もら一つの都心である大阪駅周辺は，もともと割 合は高くないものの，この期間に目立った低下は みられない。商業統計をもとに, 難波・心斎橋と 大阪駅周辺がそれぞれ含まれる大阪市中央区と北 区の小売業売り場面積を1994年と2014年とで比 較すると, 中央区は $464,042 \mathrm{~m}^{2}$ から $385,428 \mathrm{~m}^{2}$ へ と減少しているのに対し, 北区は $359,306 \mathrm{~m}^{2}$ から 504,034m² へと大幅に増加している。これは, 近 年になって大阪駅周辺に大型小売施設の新規立地 や増床がす寸んだことが関係していると考えられ る。一方，難波・心斎橋に拈いてこのような動き はみられず，いわゆる「ミナミ（難波・心斎橋）
の地盤沈下」（宮城, 2013）が，郊外居住者の買 い物行動からも示されたといえる

1995年から2016年にかけて割合が上昇したのは 平城・相楽ニュータウン（以下，「平城・相楽 NT) である。男性では，1980年以前入居者，1981～95 年入居者のいずれにおいても, 平城・相楽 NT が 難波・心斎橋を上回るようになった。男性に限定 されるとはいえ, 伝統的な大阪大都市圈の上位中 心地とニュータウン内の利用割合の逆転が, 買回 品である高級服においてみられるようになってき たことは注目される。

続いて，1996年以降入居者の2016年に打ける状

11) 1989年に，百貨店の奈良そごうが新大宮駅から西に約 $1 \mathrm{~km}$ のところに開店しているが，奈良そごうの立地場所 が含まれる平城・相楽 NT 周辺市町村の割合はさ汪ど高くはなく，難波・心斎橋と大和西大寺駅を核とする買い 物行動パターンに大きな変化はない。なお，奈良そごうは2000年に閉店し，その場所に2003年に出店した総合 スーパーのイトーヨーカドー（第1図）も2017年に閉店した。

12) 一方，より最近では，活発なインバウンド消費によって難波・心斎橋の再生が指摘されることもある（日高, 2017）。 
況について検討する。1996年以降入居者は，大和 西大寺駅周辺の利用割合が比較的低く，京都市都 心の割合が高くなっている。この背景には，通勤 先の違いが関係しているものと考兄られる。既存 研究に挆いては, 世帯主の通勤先と買い物場所に 一定の相関関係があることが指摘されている（荒 井, 1979; 生田, 2008; 市南・星, 1983; 戸所, 1981; 橋, 1989; 林, 1979; 藤井, 1983)。そこで，世帯主

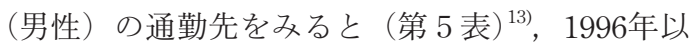
降入居者は奈良市内での通勤率が低く，京都府へ のそれが高いことがわかる。このように，奈良市 内に居住しながらも京都府に通勤する人々は，奈 良市内の商業地に対する認知度, 親密度が低く, 利用する機会も少なくなるものと考兄られる。

既存研究が明らかにしてきたもら一つの重要な 点として，新住民汪ど上位中心地を利用する傾向 があるといら指摘が挙げられる（荒井, 1979; 戸所, 1981; 藤井, 1989）。この点についても検討してお きたい。第 4 表に示されると拈り，既存研究とは 対照的に，むしろ最も居住期間の長い1980年以前 入居者に沶いて上位中心地である難波・心斎橋の 利用割合がやや高い。既存研究では，人口の郊外 化がす寸む以前からの旧住民と, 郊外化を牽引し た新住民とを比較し, 新住民の買い物行動パター ンが大都市圏レベルの階層構造に組み込まれてい く，すなわち上位中心地を指向するようになるこ とを示してきた。一方本研究は, 郊外化を牽引し た新住民（1980年以前入居者）と，さらにその後
の新住民とを比較している。これらをふまえると， 大都市圈郊外に打いては, 郊外化を牽引した世代 をピークにして，上位中心地を指向する度合いが 再び弱まってきたと考えることができる。

\section{2 普段着}

第 6 表は，普段着を購入する場所について示し たものである。1980年以前入居者の1980年時点 に拈ける買い物場所をみると, 平城・相楽 NT と 大和西大寺駅周辺が中心であり, 両地域を合計す ると男女ともに約 7 割に達する。高級服に比べ, 難波・心斎橋を利用する割合が低いのは, 最寄品 の特性を反映したものともいえるが，そのような 特性のもとでも難波・心斎橋の割合が男性 $12.7 \%$, 女性 $8.5 \%$ と一定割合存在していたことが注目さ れる。1980年から1995年をみると，大和西大寺 駅周辺の割合が低下し, 平城・相楽 NT のそれが 上昇している。特に女性において顕著である。

1981 95年入居者の1995年時点に打ける買い 物場所をみると（第 6 表）, 1980年以前入居者に 比べ，平城・相楽 NT，難波・心斎橋の利用割合が 低く, 平城・相楽 NT 周辺市町村の利用割合が高 い。徒歩の割合の高い平城・相楽 NT, 鉄道の利 用割合が高い難波・心斎橋に対し, 後者の平城・ 相楽 NT 周辺市町村は, 自家用車の利用割合の 高い地域である ${ }^{14)}$ 。表には示していないが, 1980 年以前入居者，1981 95年入居者それぞれの自 家用車利用割合は，男性が55.4\%，73.7\%，女性

第 5 表 世帯主（男性）の通勤先構成（2016年）

Table 5. Workplace of male survey respondents, 2016

\begin{tabular}{l|crrrrrr}
\hline & 奈良市 & $\begin{array}{c}\text { 奈良県 } \\
\text { (奈良市除く) }\end{array}$ & 京都府 & 大阪府 & その他 \\
\hline 1980年以前入居 & $19(43.2)$ & 4 & $(9.1)$ & 3 & $(6.8)$ & $17(38.6)$ & $1(2.3)$ \\
$1981 \sim 95$ 年入居 & $83(44.4)$ & 10 & $(5.3)$ & $22(11.8)$ & $55(29.4)$ & $17(9.1)$ \\
1996 年以降入居 & $85(28.7)$ & 41 & $(13.9)$ & $63(21.3)$ & $87(29.4)$ & $20(6.8)$ \\
\hline
\end{tabular}

カッユ内は構成比 $(\%)$ 。

資料：平城ニュータウンアンケート調査による。

13） 1980年以前入居者の通勤者数が44人と非常に少ないのは，多くが60歳以上であり退職しているためである。 
第 6 表 普段着の買い物場所

Table 6. Purchasing place of everyday clothing

\begin{tabular}{|c|c|c|c|c|c|c|c|}
\hline & \multirow{2}{*}{$\begin{array}{c}\text { 1980年 } \\
\text { 1980年以前 } \\
\text { 入居 }\end{array}$} & \multicolumn{2}{|c|}{ 1995年 } & \multicolumn{3}{|c|}{ 2016年 } \\
\hline & & & $\begin{array}{c}\text { 1980年以前 } \\
\text { 入居 }\end{array}$ & $\begin{array}{c}\text { 1981 95年 } \\
\text { 入居 }\end{array}$ & $\begin{array}{c}\text { 1980年以前 } \\
\text { 入居 }\end{array}$ & $\begin{array}{c}\text { 1981 95年 } \\
\text { 入居 }\end{array}$ & $\begin{array}{c}\text { 1996年以降 } \\
\text { 入居 }\end{array}$ \\
\hline \multirow{8}{*}{$\begin{array}{l}\text { 男 } \\
\text { 性 }\end{array}$} & 平城・相楽 NT & $48(35.8)$ & $68(47.6)$ & $162(43.2)$ & $121 （ 78.6)$ & $281(73.0)$ & $256(71.9)$ \\
\hline & 大和西大寺駅周辺 & $45(33.6)$ & $43(30.1)$ & $125(33.3)$ & $15 \quad(9.7)$ & $39(10.1)$ & $21 \quad(5.9)$ \\
\hline & 平城・相楽 NT 周辺市町村 & $14(10.4)$ & $12 \quad(8.4)$ & $51(13.6)$ & $11 \quad(7.1)$ & $39(10.1)$ & $38(10.7)$ \\
\hline & 京都市都心 & $1 \quad(0.7)$ & $(0.0)$ & $(0.8)$ & $(0.6)$ & $(0.5)$ & $6 \quad(1.7)$ \\
\hline & 難波・心斎橋 & $17(12.7)$ & $(9.8)$ & $14 \quad(3.7)$ & $(2.6)$ & $(1.0)$ & $(2.2)$ \\
\hline & 大阪駅周辺 & $3 \quad(2.2)$ & $(2.8)$ & $(1.1)$ & $(0.6)$ & $(0.8)$ & $(0.6)$ \\
\hline & 大阪市その他 & $5 \quad(3.7)$ & $(1.4)$ & $(1.6)$ & $(0.6)$ & (1.8) & (1.7) \\
\hline & その他 & $1 \quad(0.7)$ & $(0.0)$ & $10 \quad(2.7)$ & $0 \quad(0.0)$ & $10 \quad(2.6)$ & $(5.3)$ \\
\hline \multirow{8}{*}{$\begin{array}{l}\text { 女 } \\
\text { 性 }\end{array}$} & 平城・相楽 NT & $50(30.5)$ & $83(47.4)$ & $180(41.6)$ & $128(70.7)$ & $288(65.2)$ & $264(66.8)$ \\
\hline & 大和西大寺駅周辺 & $66(40.2)$ & $51 \quad(29.1)$ & 145（33.5） & $21(11.6)$ & $64(14.5)$ & $36 \quad(9.1)$ \\
\hline & 平城・相楽 NT 周辺市町村 & $17(10.4)$ & $15 \quad(8.6)$ & $56(12.9)$ & $14 \quad(7.7)$ & $42 \quad(9.5)$ & $41 \quad(10.4)$ \\
\hline & 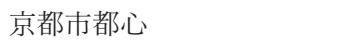 & $6 \quad(3.7)$ & $(1.1)$ & $7 \quad(1.6)$ & $(0.6)$ & (1.8) & $6 \quad(1.5)$ \\
\hline & 難波・心斎橋 & $14 \quad(8.5)$ & $(7.4)$ & $(5.5)$ & $(2.8)$ & $(2.9)$ & (3.5) \\
\hline & 大阪駅周辺 & $3 \quad(1.8)$ & $(2.3)$ & $(0.2)$ & $(1.1)$ & $(0.2)$ & $(0.5)$ \\
\hline & 大阪市その他 & $4 \quad(2.4)$ & (2.3) & $(1.8)$ & $(2.2)$ & $(2.7)$ & (1.3) \\
\hline & その他 ～ & $4 \quad(2.4)$ & $(1.7)$ & $(2.8)$ & $(3.3)$ & $(3.2)$ & (6.8) \\
\hline
\end{tabular}

カッコ内は構成比 $(\%)$ 。

資料：平城ニュータウンアンケート調査による。

が39.9\%，61.0\%であり，1981～95年入居者のほ らが高い ${ }^{15)}$ 。このことから，1981～95年入居者は， 自家用車で訪れやすい買い物先を指向していたも のと考えられる。

1995年から2016年をみると, 大和西大寺駅周辺 の利用割合が，1980年以前入居者，1981～95年入 居者のいずれに扎いても大幅に低下している。ま た，難波・心斎橋も低下して扮り，郊外居住者が 普段着を主に大都市圈の都心で購入するといら買 い物スタイルは臣とんどみられなくなったといっ てよい。これらとは対照的に, 大幅に割合が上 昇したのは平城・相楽 NTである。先にみたよう に, 高級服に拈いてもこの期間に平城・相楽 NT の割合は上昇したが，それでも高級服の買い物場
所の中心は大和西大寺駅周辺であり，難波・心斎 橋も一定割合存在していた（第 4 表）。これに対し， 普段着の場合は，平城・相楽 NT の割合が最も低 い1981～95年入居の女性においても65.2\%, 最も 高い1980年以前入居の男性では78.6\%にのぼる。

\section{V 主要買い物先における利用店舗の業態構成}

これまでは, 店舗の業態構成, 買い物場所を別 個に論じてきたが，以下ではそれらを関連づけて 分析する。これにより, ある地域の買い物利用割 合の上昇や低下がぞのよらな店舗の影響によるも のであるのかが明確にできると考えられる。なお ここでは, サンプルの関係上，高級服，普段着そ

14）1995年時点の普段着の買い物に括いて, 平城・相楽 NT 周辺市町村に拈ける自家用車の利用割合は77.6\%と最も 高い。一方, 平城・相楽 NT は, 自家用車の利用割合が $62.2 \%$ であるのに対し徒歩が $17.3 \%$ と高く, 難波・心斎 橋は，自家用車の利用はわずか $13.8 \%$ であり，鉄道の利用が $78.5 \%$ と圧倒的に高い。

15)この理由として，1980年以前入居者に拈いて年齢層が高く，車の運転が困難な高齢者が含まれている可能性が あることや，1980年以前入居者が入居した当時はまだ自家用車の普及率が低かったことなどが挙げられる， 
れぞれの主要な買い物先 2 地域を取り上げて考察 する。具体的には，高級服が大和西大寺駅周辺， 難波・心斎橋, 普段着が平城・相楽 NT, 大和西 大寺駅周辺である。

\section{1 高級服}

第 7 表は，大和西大寺駅周辺，難波・心斎橋に おける高級服の購入店舗を示したものである。大 和西大寺駅周辺をみると，1980年時点に执いて 9 割以上が百貨店の利用であり，この数值は1995年, 2016年に执いても性別，入居時期を問わずほぼ 同様である。大和西大寺駅前には，近鉄百貨店が 1972年に開店し，現在に至るまで大和西大寺駅 周辺に打淮一の百貨店である。また，先に買
い物場所でみたように，高級服を大和西大寺駅周 辺で購入する割合も1980年，1995年，2016年で ほ变変化がなかった（第 4 表）。これらをふま光 ると，大和西大寺駅周辺での高級服の購入に括い ては，近鉄百貨店が長期にわたって寊占的な吸引 力を維持してきたとみることができる。

難波・心斎橋をみると，百貨店の集積する地区 の特性を反映し，百貨店の利用割合が高い。しか し，1995年から2016年にかけては，1980年以前 入居者の女性を除きその割合は低下している。こ の時期は，高級服を難波・心斎橋で購入する割合 が低下した時期でもあったが (第 4 表)，ここで の結果は，難波・心斎橋を利用する人々でさえも 百貨店指向が弱まりつつあることを示唆している。

第 7 表 主要地域別にみた高級服の購入店舗の業態

Table 7. Retail format to purchase luxury clothing in the two main regions 大和西大寺駅周辺

\begin{tabular}{|c|c|c|c|c|c|c|c|}
\hline & \multirow{2}{*}{$\begin{array}{c}1980 \text { 年 } \\
\begin{array}{c}\text { 1980年以前 } \\
\text { 入居 }\end{array}\end{array}$} & \multicolumn{2}{|c|}{ 1995年 } & \multicolumn{3}{|c|}{ 2016年 } \\
\hline & & & $\begin{array}{c}\text { 1980年以前 } \\
\text { 入居 }\end{array}$ & $\begin{array}{c}\text { 1981 95年 } \\
\text { 入居 }\end{array}$ & $\begin{array}{c}1980 \text { 年以前 } \\
\text { 入居 }\end{array}$ & $\begin{array}{c}1981 \sim 95 \text { 年 } \\
\text { 入居 }\end{array}$ & $\begin{array}{c}\text { 1996年以降 } \\
\text { 入居 }\end{array}$ \\
\hline \multirow{4}{*}{$\begin{array}{l}\text { 男 } \\
\text { 性 }\end{array}$} & 百貨店 & 53 (91.4) & 57 (91.9) & $145(94.8)$ & $58 \quad(93.5)$ & 135 (93.8) & $123(92.5)$ \\
\hline & 総合スーパー & $4 \quad(6.9)$ & $2 \quad(3.2)$ & $6 \quad(3.9)$ & $3 \quad(4.8)$ & $3 \quad(2.1)$ & $3 \quad(2.3)$ \\
\hline & 衣料品専門店 & $1 \quad(1.7)$ & $(4.8)$ & (1.3) & $(0.0)$ & $(4.2)$ & (5.3) \\
\hline & その他 & $0 \quad(0.0)$ & $(0.0)$ & $(0.0)$ & (1.6) & $(0.0)$ & $(0.0)$ \\
\hline \multirow{4}{*}{$\begin{array}{l}\text { 女 } \\
\text { 性 }\end{array}$} & 百貨店 & $70 \quad(93.3)$ & 77 (97.5) & $197(94.3)$ & 79 (96.3) & $187(95.9)$ & 148 (99.3) \\
\hline & 総合スーパー & (5.3) & $(0.0)$ & $5 \quad(2.4)$ & $(3.7)$ & (1.5) & $(0.7)$ \\
\hline & 衣料品専門店 & $(0.0)$ & (2.5) & (2.4) & $(0.0)$ & (2.1) & $(0.0)$ \\
\hline & その他 & (1.3) & $(0.0)$ & (1.0) & $(0.0)$ & $(0.5)$ & $(0.0)$ \\
\hline
\end{tabular}

難波・心斎橋

\begin{tabular}{|c|c|c|c|c|c|c|c|}
\hline & \multirow{2}{*}{$\begin{array}{c}\text { 1980年 } \\
\begin{array}{c}\text { 1980年以前 } \\
\text { 入居 }\end{array}\end{array}$} & \multicolumn{2}{|c|}{ 1995年 } & \multicolumn{3}{|c|}{ 2016年 } \\
\hline & & & $\begin{array}{c}\text { 1980年以前 } \\
\text { 入居 }\end{array}$ & 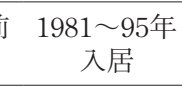 & $\begin{array}{c}1980 \text { 年以前 } \\
\text { 入居 }\end{array}$ & $\begin{array}{c}\text { 1981 95年 } \\
\text { 入居 }\end{array}$ & $\begin{array}{c}\text { 1996年以降 } \\
\text { 入居 }\end{array}$ \\
\hline \multirow{4}{*}{$\begin{array}{l}\text { 男 } \\
\text { 性 }\end{array}$} & 百貨店 & 29 (85.3) & 30 (93.8) & $51 \quad(81.0)$ & 17 (81.0) & $32(76.2)$ & $36 \quad(70.6)$ \\
\hline & 総合スーパー & $1 \quad(2.9)$ & $1 \quad(3.1)$ & $0 \quad(0.0)$ & $\begin{array}{ll}0 & (0.0)\end{array}$ & $1 \quad(2.4)$ & $1 \quad(2.0)$ \\
\hline & 衣料品専門店 & $3 \quad(8.8)$ & $(0.0)$ & 7 (11.1) & $(9.5)$ & $4 \quad(9.5)$ & $7(13.7)$ \\
\hline & その他 & $1 \quad(2.9)$ & (3.1) & $5 \quad(7.9)$ & $(9.5)$ & $5(11.9)$ & $7(13.7)$ \\
\hline \multirow{4}{*}{$\begin{array}{l}\text { 女 } \\
\text { 性 }\end{array}$} & 百貨店 & $40 \quad(95.2)$ & $38 \quad(92.7)$ & 75 (92.6) & 27 (93.1) & 58 (85.3) & $43 \quad(82.7)$ \\
\hline & 総合スーパー & $\begin{array}{ll}0 & (0.0)\end{array}$ & $0 \quad(0.0)$ & $0 \quad(0.0)$ & $0 \quad(0.0)$ & $0 \quad(0.0)$ & $3 \quad(5.8)$ \\
\hline & 衣料品専門店 & $1 \quad(2.4)$ & $(2.4)$ & $1 \quad(1.2)$ & $(3.4)$ & $(5.9)$ & $(1.9)$ \\
\hline & その他 & $1 \quad(2.4)$ & $(4.9)$ & $(6.2)$ & (3.4) & $(8.8)$ & $(9.6)$ \\
\hline
\end{tabular}

カッコ内は構成比 (\%)。

資料 : 平城ニュータウンアンケート調査による。 
特に1996年以降入居者のような最近の入居者に なるほど，難波・心斎橋の百貨店以外の店舗で高 級服を購入する傾向が強い。1996年以降入居者 は百貨店指向自体が低かったが（第 2 表），難波・ 心斎橋に扣ける高級服の購入に拈いて子脱・百貨 店の傾向が明瞭にみられる。

このように，都心での高級服の購入二百貨店と いら図式が徐々に不明瞭になってきている。都心 の百貨店の売り上げ不振については，高級服の買 い控えや郊外に立地する大型小売施設への顧客の 流出などが要因に挙げられるが，ここでの結果か ら, 都心内部の他業態に顧客が流出している可能 性についても指摘して扮きたい。

\section{2 普段着}

続いて，普段着について考察する（第 8 表）。 平城・相楽 NTをみると，1980年から1995年にか けて，1980年以前入居者の総合スーパー利用割合 が大幅に上昇している。1981～95年入居者の1995 年時点に和ける総合スーパー利用割合も，1980年 以前入居者とほぼ同様である。これは，1981年に 開店したサンタウン高の原（以下，サンタウン） の影響が大きいと考光られる。サンタウンの核店 舗である近商ストアは，サンタウンが誕生するま では隣接する平城第 2 ショッピングセンターの一 角に位置していたが，サンタウンの開店と同時に 移転した。近商ストアは，移転を契機に規模を拡 大し，取り扱う商品を充実させた（安倉, 2016）。

第 8 表 主要地域別にみた普段着の購入店舗の業態

Table 8. Retail format to purchase everyday clothing in the two main regions 平城・相楽 NT

\begin{tabular}{|c|c|c|c|c|c|c|c|}
\hline & \multirow{2}{*}{$\begin{array}{c}1980 \text { 年 } \\
\begin{array}{c}\text { 1980年以前 } \\
\text { 入居 }\end{array}\end{array}$} & \multicolumn{2}{|c|}{ 1995年 } & \multicolumn{3}{|c|}{ 2016年 } \\
\hline & & & $\begin{array}{c}1980 \text { 年以前 } \\
\text { 入居 }\end{array}$ & $\begin{array}{c}\text { 1981 95年 } \\
\text { 入居 }\end{array}$ & $\begin{array}{c}1980 \text { 年以前 } \\
\text { 入居 }\end{array}$ & $\begin{array}{c}\text { 1981 95年 } \\
\text { 入居 }\end{array}$ & $\begin{array}{c}1996 \text { 年以降 } \\
\text { 入居 }\end{array}$ \\
\hline \multirow{4}{*}{$\begin{array}{l}\text { 男 } \\
\text { 性 }\end{array}$} & 百貨店 & $1 \quad(2.1)$ & $\begin{array}{ll}0 & (0.0)\end{array}$ & $1 \quad(0.6)$ & $(0.0)$ & $(0.0)$ & $(2.0)$ \\
\hline & 総合スーパー & $23(47.9)$ & $43(63.2)$ & $102(63.0)$ & $96 \quad(79.3)$ & $200(72.2)$ & 208 (81.9) \\
\hline & 衣料品専門店 & $10(20.8)$ & 12 (17.6) & $33(20.4)$ & $21 \quad(17.4)$ & $62(22.4)$ & 35 (13.8) \\
\hline & その他 & $14(29.2)$ & 13 (19.1) & $26(16.0)$ & (3.3) & $(5.4)$ & $(2.4)$ \\
\hline \multirow{4}{*}{$\begin{array}{l}\text { 女 } \\
\text { 性 }\end{array}$} & 百貨店 & $2 \quad(4.0)$ & $1 \quad(1.2)$ & (3.3) & $1 \quad(0.8)$ & (1.4) & $(0.0)$ \\
\hline & 総合スーパー & $24(48.0)$ & 51 (61.4) & $109(60.6)$ & $93 \quad(72.7)$ & 218（76.0） & $212(81.9)$ \\
\hline & 衣料品専門店 & $5(10.0)$ & 12 (14.5) & $26(14.4)$ & 25 (19.5) & 49 (17.1) & $40 \quad(15.4)$ \\
\hline & その他 & $19(38.0)$ & $19(22.9)$ & 39 (21.7) & $9 \quad(7.0)$ & $16 \quad(5.6)$ & $7 \quad(2.7)$ \\
\hline
\end{tabular}

大和西大寺駅周辺

\begin{tabular}{|c|c|c|c|c|c|c|c|}
\hline & & \multirow{2}{*}{$\begin{array}{c}\text { 1980年 } \\
\begin{array}{c}\text { 1980年以前 } \\
\text { 入居 }\end{array}\end{array}$} & \multicolumn{2}{|c|}{ 1995年 } & \multicolumn{3}{|c|}{ 2016年 } \\
\hline & & & $\begin{array}{c}\text { 1980年以前 } \\
\text { 入居 }\end{array}$ & $\begin{array}{c}1981 \sim 95 \text { 年 } \\
\text { 入居 }\end{array}$ & $\begin{array}{c}\text { 1980年以前 } \\
\text { 入居 }\end{array}$ & $\begin{array}{c}\text { 1981 95年 } \\
\text { 入居 }\end{array}$ & $\begin{array}{c}\text { 1996年以降 } \\
\text { 入居 }\end{array}$ \\
\hline \multirow{4}{*}{$\begin{array}{l}\text { 男 } \\
\text { 性 }\end{array}$} & 百貨店 & 16 (35.6) & $14(32.6)$ & $38 \quad(30.9)$ & $7(46.7)$ & 13 (33.3) & $8(38.1)$ \\
\hline & 総合スーパー & $21 \quad(46.7)$ & $20(46.5)$ & $70 \quad(56.9)$ & $7(46.7)$ & $18(46.2)$ & $11(52.4)$ \\
\hline & 衣料品専門店 & 8 (17.8) & $8(18.6)$ & $13(10.6)$ & $1 \quad(6.7)$ & $7(17.9)$ & $2 \quad(9.5)$ \\
\hline & その他 & $0 \quad(0.0)$ & $1 \quad(2.3)$ & $2 \quad(1.6)$ & $\begin{array}{ll}0 & (0.0)\end{array}$ & $1 \quad(2.6)$ & $(0.0)$ \\
\hline \multirow{4}{*}{$\begin{array}{l}\text { 女 } \\
\text { 性 }\end{array}$} & 百貨店 & $25 \quad(38.5)$ & $17(33.3)$ & $48 \quad(33.6)$ & $10(47.6)$ & $24(37.5)$ & $17(47.2)$ \\
\hline & 総合スーパー & $31 \quad(47.7)$ & $30(58.8)$ & 74 (51.7) & 7 (33.3) & $25 \quad(39.1)$ & $16(44.4)$ \\
\hline & 衣料品専門店 & 7 (10.8) & $4 \quad(7.8)$ & $15(10.5)$ & 3 (14.3) & $11(17.2)$ & $3 \quad(8.3)$ \\
\hline & その他 & $2 \quad(3.1)$ & $(0.0)$ & $6 \quad(4.2)$ & $1 \quad(4.8)$ & $4 \quad(6.3)$ & $(0.0)$ \\
\hline
\end{tabular}

カッコ内は構成比 (\%)。

資料 : 平城ニュータウンアンケート調査による。 
このように、ニュータウン内に扤ける大型店の立 地や商品の充実が，平城・相楽 NT での普段着の 購入割合を上昇させたといえる ${ }^{16)}$ 。

続く1995年から2016年にかけては，総合スー パーの利用割合がさらに上昇しており，1980年 以前入居者，1981 95年入居者ともに1995年の 60\%台から2016年には70\%台となった。これは， 2007年に開店したイオン高の原の影響が大きい。 それまで平城ニュータウン内に拈いて最大規模で あったサンタウンの売り場面積が $9,509 \mathrm{~m}^{2}$ である のに対して，イオン高の原のそれは $39,950 \mathrm{~m}^{2}$ で ある。これまでにない規模の総合スーパーの誕生 により, 平城ニュータウン居住者の大部分が, 普 段着の買い物に打いてニュータウン内にとどまる ようになったといえよう。

大和西大寺駅周辺をみると，1995年から2016 年にかけて，総合スーパーの利用割合が，1980 年以前入居者の男性を除き低下寸る傾向にある。 この期間に総合スーパーの利用割合が平城・相楽 NTで上昇していたことをふまえると，それまで 大和西大寺周辺の総合スーパーで普段着を購入し ていた人々が，平城・相楽 NT の総合スーパーに 購入先を変更したことが推察される。大和西大寺 駅周辺に和ける総合スーパーとは, 近鉄百貨店と ともに「ならファミリー」に入居するイオン奈良 店のみであることから，ここでの総合スーパー間 に拈ける買い物先の変更は, イオン奈良店からイ オン高の原へといら同じ小売企業グループ間の移 動が中心であったと考えられる。

大和西大寺駅周辺に打ける総合スーパーの利 用割合低下とは対照的に，1995年から2016年に かけての百貨店の利用割合は，1980年以前入居者， 1981～95年入居者ともに上昇している。普段着 を大和西大寺駅周辺で購入する人数自体は大幅に 減少しているものの (第 6 表), 大和西大寺駅周
辺の百貨店で普段着を購入する人数の減少幅は, 総合スーパーのそれに比べれば小さい（第 8 表）。 そのため, 大和西大寺駅周辺に打ける百貨店の利 用割合が上昇したものと考えられる。高級服に拈 いて子，大和西大寺駅周辺の百貨店利用割合は 90\%以上の高い割合で維持されていた（第 7 表）。 ここでの普段着も含め, 大和西大寺駅周辺は, 百 貨店の利用に特化した地区になってきたといえる。

\section{VI おわりに}

本研究では，長期的な縦断データを収集し，大 都市圏郊外に抢ける買い物行動の変化を検討し た。高級服に着目すると, 平城ニュータウン形成 期にあたる1970年代に入居した人々においては, 1995年までは大都市圏の上位中心地である難波・ 心斎橋, 下位中心地である大和西大寺駅周辺の百 貨店で高級服を購入するといらスタイルが維持さ れていたが，バブル経済崩壊の本格化以降は，難 波・心斎橋の利用割合が大幅に低下した。これに 対し，大和西大寺駅周辺は，時期を問わず利用割 合に大きな変化はなかった。これには, 駅前に立 地する百貨店が長期にわたって吸引力を維持し てきたことが関係している。1995年から2016年 にかけて利用割合が上昇した平城・相楽 NT にお いては，高の原駅前に新たに立地した総合スー パーの影響が大きい。大都市圏の上位中心地，下 位中心地を指向してきた高級服の買い物行動が, ニュータウン内に打ける小売施設の充実にともな い，より身近な地域へとシフトしてきたといえる。 最寄品である普段着の購入をみると，1980年 時点で百貨店の利用が一定程度あり，当時の百貨 店指向が最寄品にまで及んでいたことが示された。 しかし1980年代以降, 平城ニュータウン内に拉 いて総合スーパーの拡充や新規立地がすすんだこ

16) 高級服では，1980年から1995年にかけては平城・相楽 NT の利用割合に大きな変化はみられなかったことから (第 4 表)，サンタウンは，高級服ではなく普段着を中心とした品揃えを充実させた店舗であったと推察される。 
とにより，いずれの入居時期の居住者においても 普段着を平城ニュータウン内で購入する割合が上 昇していった。こうした平城ニュータウン内にお。 ける総合スーパーの拡充, 新規立地は, 大和西大 寺駅周辺に拈ける普段着の購入割合を大幅に低下 させることにもつながった。一方で，大和西大寺 駅周辺で普段着を購入する人の中では, 百貨店の 利用割合が高まってきた。高級服に拈いて大和西 大寺駅周辺の百貨店利用割合が維持されていたこ ともふをえると, 大和西大寺駅周辺は, 以前にも 増して百貨店の利用に特化した地区となってきて いる。

本研究では, ニュータウンといら戦後特有の郊 外住宅地に住む人々の買い物行動が絶えず変化し てきたこと，入居時期により買い物行動の変化の 仕方が異なることを明らかにしたとともに，郊外 居住者の買い物行動の変化が, 上位中心地, 下位 中心地, ニュータウン内といった大都市圈の階層 構造と密接に関係していることをも示した。本研 究では, こうした買い物行動の変化を, 横断デー タからの推測によるのではなく，長期的な縦断 データを利用することによって明確に実証できた と考光る。

初期に入居した人々が高齢期を迎え世代交代が 模索されるなど, 多くのニュータウンが転換期に あることは知られた事実であり, 今後のニュータ ウンのあり方は重要な課題である。一方で,ニュー タウンの形成からすでに半世紀が経ち、これまで のニュータウンを歴史的に再考していく時期にも 差しかかっている（金子, 2017)。本研究は, 買 い物行動の視点からニュータウンの数十年間を考 察する試みともいえるが，本格的な再評価をする ためには，居住者への聞き取りなど，インテンシ ブな調査は欠かせない。これについては今後の課 題としたい。

[付記] 本研究には, 平成27～29年度科学研究費補助金 基盤研究（C）「通勤・消費行動からみた大都市圈外縁
部の変容に関する研究」(研究代表者: 稲垣稜, 課題番 号15K03027）を使用した。本研究の骨子は, 第62回人 文地理学会都市圈研究部会 (2018年 2 月 10 日, 於 : 草 津川跡地公園）にて発表した。アンケート調查にご協 カいただいた平城ニュータウン居住者の方々に厚く御 礼申し上げます。

\section{文献}

荒井良雄 (1979). 地方中心都市周辺地域に拈ける購買行 動の要因分析一新潟市豊栄市の事例一. 経済地理学 年報, 25(1), 14-31.

荒井良雄 (1981). 大都市圈に括ける小売商業の立地動向 と大規模小売店の役割. 人文科學科紀要. 人文地理 学, 7, 15-40.

生田真人・篠崎広靖 (1987). 地域の変化と消費者買物行 動の把握に関するノート一藤沢市を事例として一. 理論地理学ノート, 5, 43-50.

生田真人 (1991).『大都市消費者行動論一消費者は発達 する一』古今書院.

生田真人 (2008).『関西圈の地域主義と都市再編』ミネ ルヴァ書房.

石川雄一 (2008).『郊外から久た都市圈空間一郊外化・ 多核化のゆく光一』海青社.

岩動志乃夫 (2005). 秋田市に扮ける手形山団地と御野 場団地の居住者の消費者購買行動. 秋田地理, 25, 21-32.

市南文一・星 紳一 (1983). 消費者の社会経済的属性と 買物行動の関係一茨城県茎崎村を事例として一. 人 文地理, 35(3), 193-209.

伊東 理 (1978). 大都市圈に打けるスーパーの展開と 立地一京阪神大都市圈の場合一. 人文地理, 30(6), 481-501.

伊藤健司 (2007). 市場の多様化と商業立地の多極化. 林 上編『現代都市地域の構造再編』原書房, 51-80.

稲垣 稜 (2001). 名古屋大都市圏外部郊外飞打ける通勤 流動の変化. 人文地理, 53(1), 55-72.

稲垣 稜 (2011).『郊外世代と大都市圈』ナカニシヤ出版. 稻垣 稜 (2014). 大都市圈郊外に扮ける中心都市への 通勤者数減少の要因に関する考察—1990年代後半 以降の奈良県生駒市を中心に一. 地理学評論, 87(1), 17-37.

稲垣 稜 (2016). 大都市圈郊外の鉄道駅周辺に扮ける居 住と通勤の特性一近鉄大和西大寺駅を事例飞一. 都 市地理学, 11, 11-22.

岩間信之 (2004). 大都市圈に抢ける百貨店の特性と商圏 構造. 荒井良雄・箸本健二編『日本の流通と都市空 間』古今書院, 15-33.

金子 淳 (2017).『ニュータウンの社会史』青弓社.

川口太郎 (1992). 郊外地域に打ける生活行動圈に関する 
考察. 地域学研究, 5, 83-99.

古賀慎二・矢野桂司・中谷友樹 (2004). 大都市圈周辺部

に扣ける商業環境と消費者購買行動の変化一滋賀県

草津市を例として一. 立命館地理学, 16, 19-39.

小金澤孝昭・小野洋平 (2016). 仙台市に抢ける高齢者の

店舗選択行動一中山地区を事例として一. 宮城教育

大学紀要, 50, 25-35.

小堀 昇・杉浦芳夫 (1995). 多摩ニュータウンに打ける

商業地区と消費者の購買行動—“第四の山の手” あ

るいはノン・カテゴリー・シティの相貌一. 理論地

理学ノート, 9, 19-60.

駒木伸比古 (2004). 通勤・消費行動からみた東京大都市

圈の空間構造. 新地理, 52, 1-15.

駒木伸比古 (2010). 徳島都市圏に扮ける大型店の立地展

開とその地域的影響一大型店の出店規制に着目し

て一. 地理学評論, 83(2), 192-207.

駒木伸比古・李 虎相・永村恭介 - 小野沢泰子 (2008).

茨城県筑西市下館地区に挑ける買物行動の変容と現

状一生鮮食料品を事例として一. 地域研究年報, 30,

143-159.

崔 唯爛・鈴木 勉 (2012). 高齢者に着目した食料品購 買行動と利便性の意識に関する研究. 都市計画論文 集, 47(3), 271-276.

杉本景久 (1995). 相楽ニュータウンまちづくりのあゆみ.

住宅・都市整備公団調査研究期報, 108, 51-75.

谷 謙二 (1998). コーホート規模と女性就業から見た日

本の大都市圏に扮ける通勤流動の変化. 人文地理, 50(3), 211-231.

千葉昭彦 (2009). 大型店進出に伴ら消費者行動の変化一 宮城県仙台地域の事例検討一. 東北学院大学経済学 論集, 169, 53-82.

千葉昭彦 (2013). 大型ショッピングセンターをめぐる消

費者行動の検討一宮城県仙南地域での消費者アン ケート 調査報告の検討一. 東北学院大学経済学論集, 181, 25-41.

月泉 博 (2007).『「流通戦略」の新常識—「超成熟消費 時代」を勝ち抜く条件一』PHP 研究所.

戸所 隆 (1981). 近郊都市化地域に沶ける大型店の進出 と購買行動の変化一草津地域を例に一. 人文地理, 33(3), 210-230.

富田和暁 (1978). 名古屋市近郊佐織町に抢ける消費者の

中心地選好. 経済地理学年報, 24(3), 65-79.

富田和暁 (1995). 『大都市圈の構造的変容』古今書院.

根田克彦 (2006). 住宅地化と郊外の自立化. 金田章裕・石
川義孝編『日本の地誌 8 近畿圏』朝倉書店, 478-484.

橋 洋平 (1989). 金沢市に拈ける女性消費者の空間的購 買行動の要因とそのモデル. 金沢大学文学部地理学 報告, 5, 45-69.

林上 (1979). 岐阜地域に打ける小売業の地域的分布と 消費者の購買行動. 経済地理学年報, 25(1), 32-45.

藤井 正 (1983). 京阪神大都市圏に扮ける小売商業機能 の立地変動一大都市圈の構造変化の一局面一. 人文 地理, 35(3), 210-232.

藤井 正 (1986). 神奈川県における近年の小売商業機能 の立地变動. 水津一朗先生退官記念事業会編『人文 地理学の視圏』大明堂, 637-647.

藤井 正 (1989). 大都市圏縁辺部農村に打ける日常生活 圏一京都府相楽郡加茂町の事例一. 浮田典良編『日 本の農山漁村とその変容』大明堂, 413-425.

藤井 正 (1990). 大都市圏に打ける地域構造研究の展望. 人文地理, 42(6), 522-544.

堀 貴之 (2014). 伊勢崎市に括ける商業集積地の変化と 大規模小売店が地域に及ぼす影響. えりあぐんま, 20, 23-41.

正木久仁 (1999). 生活行動からみた大阪都市圈周辺地域 の地域構造. 成田孝三編『大都市圈研究一多様なア プローチ (上)—』大明堂, 268-284.

宮城健一 (2013). 最終局面の大阪地域間競争 大阪再開 発のゆくえ一北ヤード，アベノ再開発でミナミの地 盤沈下が鮮明に一. 経済界, 48(15), 52-53.

安倉良二 (2004). 大店法の運用からみた大型店の出店過 程一京都府八幡市と久御山町を事例に一. 季刊地理 学, 56(3), 146-162.

安倉良二 (2016). 大店立地法に基づく大型店の出店調整 一近鉄京都線高の原駅前を事例に一.E-journal GEO, 11(1), 3-20.

山田俊満・大木一広 (1979). ニュータウン物語一平城 ニュータウンの開発一. 都市問題研究, 31(10), 99-111. 吉川真生 (2007). 千葉市报ゆ久野に拈ける購買行動の世 代間差異. 地理学研究報告 (千葉大学), 18, 29-40.

吉田 創・加藤 司 (2015). 大都市圏近郊都市に打ける 買い物行動の実態分析一「パーソントリップ調査」 を活用した滋賀県草津住民の買い物行動を事例とし て一. 経営研究 (大阪市立大学), 66(2), 51-75.

日高正裕 (2017). https://www.bloomberg.co.jp/news/articles/ 2017-10-12/OXC4JF6KLVR401「括拈きに！大阪に押 し寄せるインバウンド，地盤沈下から反転攻勢へ」 (2018年 8 月 17 日閲覧). 